\title{
PRINSIP KESETIAAN MELAYANI RASUL PAULUS: SEBUAH STUDI EKSEGETIS KISAH PARA RASUL 20:24
}

David Susilo Pranoto

davidsusilopranoto@sttab.ac.id

\begin{abstract}
The God who calls believers into the noble calling task is a faithful God. In carrying out this call of duty the believer must be faithful like God the creator. The task of that vocation is to serve God and preach the gospel throughout the face of the earth. Loyalty to serve to the end is what God wants for every believer, this must be owned by every servant of God and believers, as the Apostle Paul emphasized in the book "Acts 20" as a servant of the Lord the Apostle Paul completed his vocation properly. In "Revelation 2: 10b" let you be faithful unto death, I will grant you the crown of life. This is God's promise for everyone who is faithful to Him and who completes the call of duty well to the finish line. Through the article is expected to encourage believers to understand eating loyalty.
\end{abstract}

Keywords: Principles, Loyalty, Serving, Exegetical Studies.

Abstraksi: Allah yang memanggil orang percaya masuk dalam tugas panggilan yang mulia adalah Allah yang setia. Dalam menjalankan tugas panggilan tersebut orang percaya harus setia seperti Allah sang pencipta. Tugas panggilan itu adalah melayani Tuhan dan memberitakan Injil keseluruh muka bumi. Kesetiaan melayani sampai akhir merupakan hal yang diinginkan oleh Tuhan bagi setiap orang percaya, hal ini harus dimiliki setiap hamba Tuhan dan orang percaya, seperti halnya Rasul Paulus menekankan dalam kitab "Kisah Para Rasul 20" sebagai hamba Tuhan Rasul Paulus menyelesaikan tugas panggilannya dengan baik. Dalam "Wahyu 2:10b” hendaklah engkau setia sampai mati, Aku akan mengaruniakan kepadamu mahkota kehidupan. Inilah janji Tuhan bagi setiap orang yang setia kepadaNya dan yang menyelesaikan tugas panggilan dengan baik sampai garis akhir. Melalui artikel diharapkan dapat mendorong orang percaya memahami makan kesetiaan.

Kata Kunci: Prinsip, Kesetiaan, Melayani, Studi Eksegetis.

\section{LATAR BELAKANG}

Kesetiaan adalah karakter Allah yang berlimpah-limpah kasih dan setiaNya.Allah adalah setia dan memegang perjanjianNya.Dia adalah Allah yang setia dan tidak ada kecurangan. Kesetiaan akan nampak dengan nyata pada waktu menghadapi ujian, sebab tendesi manusia adalah setia jika keadaan baik dan enak serta menyenangkan. Ketika badai kesulitan dan tantangan datang maka jangkar kesetiaan itu akan diuji. Setia kepada seseorang jika orang tersebut memberikan keuntungan yang dicarinya, jika tidak maka 
kesetiaan itu pudar setia kepada kepada hal-hala kecil lebih sulit dari pada setia kepada hal-hal yang besar. ${ }^{1}$ Kesetiaan bukan berarti ketaatan yang pasif, tetapi dari hal yang kecil dalam kesetiaan dapat mengembangkannya menjadi sesuatu yang lebih besar demi kemuliaan Tuannya (Mat. 25:14-30). ${ }^{2}$ Itulah gambaran kesetiaan manusia. Kesetiaan yang di maksud dalam teks ini ialah kesetiaan di dalam melakukan firman Tuhan dan Kesetiaan terhadap Allah pencipta serta pemilik alam semesta. Di mana dalam mempertanggungjawabkan segala pekerjaan itu adalah kepada Allah.

Jadi kesetiaan hamba harus siap untuk mengorbankan banyak hal, tidak memanjakan diri, tetapi melatih diri untuk tetap teguh, kuat untuk mencapai garis akhir dengan baik.Estabrooks mengatakan: Menjadi seorang pengikut Yesus berarti menjadi murid Yesus. Seorang murid adalah seorang yang menjadi mirip dengan orang yang diikutinya, seseorang yang mencontoh gurunya dalam segala hal. ${ }^{3}$ Seperti halnya juga seorang hamba dalam mengikuti tuannya dalam banyak hal. Dalam hal ini pribadi yang perlu di tiru adalah Tuhan Yesus sendiri,dimana Ia menjadikan DiriNya Hamba, dan taat sampai mati itulah bukti kesetiaan kepada Bapa.Sebagai seorang pelayan haruslah melakukan seperti yang Tuhan lakukan.Sebab Allah tidak menginginkan pengakuan dibibir tetapi nyata dalam pola kehidupan setiap hari. Bagaimana mungkin seorang pelayan menyebut dirinya setia, tetapi yang terlihat dari pola hidup setiap hari tidak sesuai dengan apa yang dikehendaki Allah.

Seorang tabib diperlukan oleh orang yang sakit, begitu halnya Veerman mengatakan bahwa“Anak Manusia datang bukan untuk dilayani melainkan untuk melayani, dan untuk memberikan nyawaNya menjadi tebusan bagi orang banyak (Mar. 10:45), melayani dan memberikan memang radikal sifatnya, dan kita pun dipanggil untuk melakukan hal ini"4 Demikianlah Tuhan menunjukkan kesetiaanNya lewat pengorbananNya di atas kayu salib.

Dalam 1 Korintus 2 dan 4, Paulus membeberkan katalog hidupnya di dalam Kristus.Itu bukan kisah tentang damai, tetapi penolakan dan penderitaan.Oleh karena itu, kami tidak memberitakan Injil kemakmuran melalui berkat.Kami memberitakan gambaran sejati dari Allah yang menang dikayu salib dan putraNya yang berkemenangan (Yoh. 15:20; 16:33). ${ }^{5}$

\footnotetext{
${ }^{1}$ Bagus Surjantoro, Pemenang (Jakarta: lembaga Alkitab Indonesia, 1997), 23

${ }^{2}$ Ibid...,23

${ }^{3}$ Paul Estabrooks, Berdiri Teguh Ditengah Badai (Jakarta:open doors internasional 2001), 310

${ }^{4}$ Dave Veerman, Pola Hidup Kristen (Malang: Gandum Mas, Yakin, Kalam Hidup, 1989),965

${ }^{5}$ Paul Estabrooks, Berdiri Teguh Ditengah Badai (Jakarta: Open doors Internasional 2001),312
} 
Barclay mengatakan bahwa Kasih terhadap sesama menunjukkan karakter seorang hamba lewat pola hidupnya sehari-hari.Kesetiaan dalam melayani sangat ditentukan oleh kasih seorang kepada Tuhan. Demikian juga kesucian tetap terpelihara bila seorang pelayan memiliki kasih yang sama itu. ${ }^{6}$ Paulus menyebut unsur-unsur perkataan, tingkah laku, kesucian yang mencerminkan kata dan perbuatan. Seorang pelayan harus seperti Timotius meskipun Timotius masih muda sementara ia harus menghadapi sejumlah anggota jemaat yang mungkin lebih tua untuk menerima nasehatnya. Tetapi dengan keteladanan itu ia mewujudkan dengan kata dan perbuatan, memungkinkan ia melakukan tugasnya.

\section{MAKNA UNGKAPAN RASUL PAULUS TENTANG "KESETIAAN MELAYANI SAMPAI AKHIR" BERDASARKAN KISAH PARA RASUL 20:24}

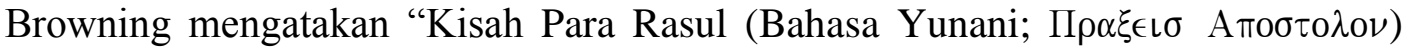
adalah buku kelima Perjanjian Baru pada Alkitab Kristen, berisi tentang pertama kali terbentuknya gereja Kristen serta pertumbuhannya sampai pada pertengahan abad pertama Masehi. ${ }^{7}$ Dalam masa pelayanan Yesus di dunia, kemunculan gereja dan kebangunan rohani dalam kekristenan mula-mula merupakan suatu catatatn sejarah yang sangat menggugah hati setiap orang percaya.kemajaun yang signifikan terjadi dalam kekristenan. Ada banyak orang menjadi percaya melalui pelayanan para rasul. Kisah Para Rasul menggambarkan prosedur serta keberhasilan suatu gereja yang dibangun berdasarkan pokok-pokok yang dikaruniakan Roh Kudus ${ }^{8}$ Marshall mengatakan:

Amanat Kisah Para Rasul ini menjelaskan bagaimana pengikutpengikut Yesus Kristus dengan pimpinan Roh Kudus menyebarkan kabar baik tentang Yesus "di Yerusalem, di Yudea, di Samaria, dan sampai ujung bumi" (1:8).Buku ini adalah cerita tentang pergerakan Kristen yang dimulai di antara orang Yahudi lalu meluas menjadi suatu agama untuk seluruh dunia, tidak hanya untuk orang Yahudi. Penulis kitab ini merasa perlu meyakinkan para pembacanya bahwa orang-orang Kristen bukanlah suatu bahaya politik subversif terhadap kekaisaran Romawi, tetapi bahwa agama Krsiten merupakan penyempurnaan agama Yahudi $^{9}$

${ }^{6}$ Robert P. Borrong, Berakar Didalam Dia Dan DibangunDdi atas Dia (Jakarta: BPK Gunung Mulia 2002),21

${ }^{7}$ W.R.F. Browning, Kamus Alkitab (Jakarta: BPK Gunung Mulia, 2007), 208

${ }^{8}$ Merrill C. Tenney, Survei Perjanjian Baru, (malang: Gandum Mas 1997), 292

${ }^{9}$ Howard Marshall, Tyndlae New Tastement Comentaries, (England: Act. England. Intervasity Press, 1980), 28 
Berdasarkan pendapat Marshall penulis menyimpulkan bahwa Kisah Para Rasul secara khusus ingin menyampaikan sejarah awal tentang kekristenan. Selain merupakan gambaran sekilas tentang kehidupan gereja generasi pertama, Kisah Para Rasul juga berusaha menggambarkan kondisi gereja-gereja secara runtut serta memberikan banyak informasi tentang tatanan gereja mula-mula atau tata ibadah mereka. ${ }^{10}$ Kelanjutan karya Yesus tersebut merupakan perluasan pelayanan gereja yang dipimpin oleh Roh kudus (Kis. 1:8). Dengan pimpinan dan kuasa Roh Kudus, Injil akan didengar di Yerusalem, Yudea dan Samaria, bahkan sampai ke ujung-ujung bumi (Mat. 28:19-20), karena itulah yang dikehendaki Allah bagi pelayan Tuhan dan bagi orang percaya memberitakan Injil sampai ke ujung bumi dan ketahuilah bahwa Allah selalu menyertai sampai akhir zaman.

Berikut ini eksegese beberapa kata penting yang dapat memberikan pemahaman yang dalam bagi orang percaya terlebih-lebih bagi pengurus gereja sebagai pelayan Tuhan tentang makna ungkapan "Kesetiaan Melayani Sampai Akhir" yang terdapat dalam Kisah Para rasul adalah sebagai berikut:

Rasul Paulus" Tidak Menghiraukan Nyawanya" Dalam bahasa Yunani kata

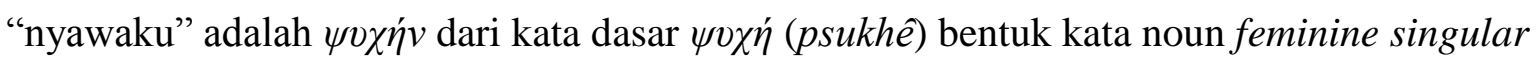
accusative, kata benda tunggal bersifat objek langsung, yang berarti jiwa, nyawa, hidup, hati, orang. ${ }^{11}$ Dalam Kamus Besar Bahasa Indonesia nyawa diartikan pemberi hidup kepada wadah (organisme fisik) yang menyebabkan hidup pada manusia, keadaan yang sulit, dan berbahaya. ${ }^{12}$ Dalam King James Version memakai kata "neither count I my life dear unto my self, ${ }^{13}$ artinya ia tidak memperhitungkan hal yang berharga nyawa maupun jiwanya asal saja ia mencapai garis akhir dan setia sampai mati. Artinya Paulus mengorbankan hal yang berharga, asal saja ia mencapai garis akhir. Dalam The Interlinear Greek-English New Testament memakai kata "But of nothing account I make", ${ }^{14}$ artinya meski saya harus memberikan nama/harga Rasul Paulus menganggap itu semua tidak penting, asal saja Paulus memperoleh mahkota.

${ }^{10}$ Donald Guthrie, Pengantar Perjanjian Baru Volume 1(Surabaya: Momentum, 2008), 309310

${ }^{11}$ Hasan susanto, Perjanjian Baru Interlinear Yunani-Indonesia dan Konkordansi Perjanjian Baru (PBIK) Jilid I(Jakarta; Lembaga Alkitab Indonesia), 753, 827

${ }^{12}$ Dendy Sugono, Kamus Besar Bahasa Indonesia (Jakarta: Gramedia Pusat Bahasa, 2011),972

${ }^{13}$ Jay P. Greeen, The Interlinear Greek-English New Testament (Indiana: Associated Publishers \& Authors, 1976), 387

${ }^{14}$ Jay P. Greeen, The Interlinear Greek-English New Testament(Indiana: Associated Publishers \& Authors, 1976), 387 
Fokus utama Rasul Paulus bukanlah mempertahankan hidupnya; yang paling penting baginya ialah bahwa ia dapat menyelesaikan pelayanan yang dipercayakan Allah kepadanya. Di manapun tugas itu berakhir, bahkan dengan mengorbankan nyawanya sekalipun ia akan menyelesaikan pelayanannya dengan sukacita dan doa agar "Kristus dengan nyata dimuliakan di dalam tubuhku baik oleh hidupku, maupun matiku" Filipi 1:20 Bagi Paulus, hidup dan pelayanan bagi Kristus adalah sama dengan perlombaan yang harus diikuti dengan kesetiaan mutlak bagi Tuhannya Kis 13:25; 1Kor 9:24; 2 Tim 4:7; Ibr 12:1.

Paulus dipenjarakan, dicambuk, dirajam, diusir oleh bangsanya sendiri, tetapi sebaliknya ia selalu bersukacita di dalam Roh Kudus. Menderita kesusahan karena Kristus bukan menandakan bahwa Allah telah meninggalkan kita, melainkan Allah menyertai umatNya. ${ }^{15}$ Sekalipun tubuh ini tersiksa, bagi Paulus hal itu akan membawa sukacita bagiNya, sebab Paulus percaya bahwa Tuhan Yesus tidak pernah meninggalkannya, bahkan Paulus terus mengingatkan orang-orang pada waktu itu agar tetap mengasihi Kristus lebih dari nyawa mereka sendiri.

Calvin mengatakan bahwa standar penyangkalan diri tidak hanya memikirkan orang lain dengan lebih baik dari pada diri sendiri, tetapi sebenarnya marilah kita mengusahakan kebaikan orang lain, bahkan dengan sukarela melepaskan hak-hak kita demi kepentingan orang lain. ${ }^{16}$ artinya hendaklah setiap orang percaya dengan sukarela memberi diri sepenuhnya kepada Allah

Calvin menjelaskan bahwa:

"Dasar dari sikap ini adalah bahwa semua orang diciptakan sesuai dengan gambar Allah, dan kepada mereka kita berutang seluruh penghormatan dan kasih yang dapat kita berikan. Hal ini benar terutama bagi umat percaya lainnya, karena mereka telah dihidupkan di dalam Kristus melalui karya Roh Kudus. Namun bahkan jika seseorang melakukan perbuatan tercela dan tidak berharga, ia masih menyandang keserupaan dengan Allah dan oleh karena itu ia layak menerima rasa hormat dan pertolongan ketika ia memerlukannya. Dan Tidak ada seorang pun yang sungguh-sungguh telah menyangkal dirinya jika dia belum menyerahkan dirinya sepenuhnya kepada Tuhan dan rela memercayakan setiap detail kehidupannya kepada kerelaan kehendakNya $^{17}$

\footnotetext{
${ }^{15}$ Wesley Brill, Tafsiran Surat Tesalonika (Bandung: Kalam Hidup, 2008), 48

${ }^{16}$ John Calvin, Sebuah Hati Untuk Ketaatan (Surabaya: Momentum, 2014), 244

${ }^{17}$ Ibid..245
} 
Berdasarkan pemahaman diatas Penulis menyimpulkan bahwa hamba yang tidak sungguh-sungguh menyerahkan dirinya sepenuhnya kepada Allah, sangat susah baginya untuk menyangkal diri demi melayani Tuhan, tetapi hamba yang setia adalah hamba yang sungguh-sungguh menyerahkan diri sepenuhnya dan menyangkal diri.

\section{Rasul Paulus bertekad "Mencapai Garis akhir"}

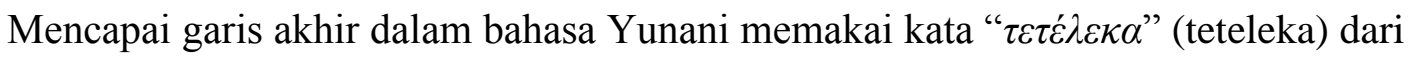
kata dasar " $\tau \varepsilon \lambda \varepsilon \dot{\varepsilon} \omega$ " (telow). ${ }^{18}$ Dalam bentuk verb first person singular perfect active indicative yang artinya kata kerja yang dilakukan seseorang secara terus menerus dengan sempurna.Dan memiliki arti mengakhiri, menyelesaikan, melakukan, menaati, mewujudkan.Dalam Kamus Besar Bahasa Indonesia kata akhir memiliki arti kesudahan, penghabisan. ${ }^{19}$ Jadi mencapai garis akhir adalah menyelesaikan atau mengakhiri sebuah pelayanan yang telah dipercayakan kepada setiap pelayan Tuhan

Aku dapat mencapai garis akhir dan menyelesaikan pelayanan: yang dimaksud dengan perkataan ini ialah "untuk menyelesaikan perlombaan dan pelayanan." kata perlombaan (mencapai garisakhir) disini sama dengan yang di 2Timotius 4:7. Artinya bahwa Rasul Paulus bertanding lari, tetapi sebagai kiasan untuk tugas yang telah Allah berikan kepada Paulus. $^{20}$

Henry mengatakan bahwa: keberhasilan Paulus dalam melayani yaitu Paulus berhasil memberitakan Injil bahkan jemaat yang dilayaninya semakin diteguhkan didalam Tuhan dan secara Rohani mereka dibangun,sehingga mereka terus meyakini bahwa anugerah itu bukan dari hasil usaha mereka akan tetapi pemberian Allah.

Berdasarkan pendapat di atas Penulis menyimpulkan bahwa ketika Rasul Paulus mengatakan "saya telah mencapai garis akhir"berarti rasul Paulus telah berhasil memberitakan Injil walaupun Paulus mengalami berbagai tantangan dan cobaan, sebab rasul Paulus yakin bahwa Allah yang menguatkannya dan dapat menaklukkan itu semua.

Sepertihalnya Murray juga mengatakan "Hendaklah kamu kuat di dalam Tuhan, di dalam kekuatan kuasaNya, pertandingan yang baik adalah karena Tuhan Yesus yang memberi kemenangan itu. Maka hanya Ia sendirilah yang dapat menaklukkan musuh". ${ }^{21}$ Jadi dalam melawan musuh bukan dengan kekuatan dan kehebatan manusia

\footnotetext{
${ }^{18}$ Ibid., 1136

${ }^{19}$ Dendy Sugono, Kamus Besar Bahasa Indonesia (Jakarta: 2011), 27

${ }^{20}$ Barclay M. Newman, Kisah Para Rasul (Jakarta: Yayasan Karunia Bakti Budaya Indonesia, 2008), 576

${ }^{21}$ Andrew Murray, Membina Iman (Bandung:Kalam hidup, 1980), 120
} 
tetapi hanyalah dengan kuasa Tuhan Yesus Kristus.Yang adalah sumber kekuatan bagi orang percaya.

Jadi tantangan yang dihadapi Rasul Paulus bukan hanya dari orang-orang pada saat itu, tetapi tantangannya adalah bagaimana Rasul Paulus dapat mencukupi keperluan dan kebutuhannya sendiri dengan menjual tenda.

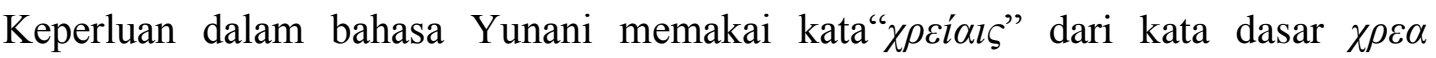
(kheria) dalam bentuk noun feminine plural dative yang menyatakan perempuan jamak sebagai objek tidak langsung.Artinya keperluan, kebutuhan, kekurangan, tugas.Dalam Kamus Besar Bahasa Indonesia kata "keperluan" adalah sebuah keharusan, kemestian, yang perlu. Dalam terjemahan Exegetical Dictionary of the new tastemant menggunakan kata Cheria need, necessity (keperluan-keperluan). ${ }^{22}$ Jadi secara harafiahnya kata memenuhi keperluan bararti mencukupi apa yang ada, melayani, bahkan memberi untuk mencukupi kebutuhan-kebutuhan yang lain.

Marshall berkomentar bahwa "untuk memenuhi keperluanku" Paulus menolak untuk menerima bantuan dari para jemaat yang sedang ia layani karena tuduhan terus menerus oleh guru-guru palsu tentang motifasinnya. Paulus memenuhi kebutuhannya sendiri dengan membuat tenda (Lih. 1 Kor. 4:12; 9:3-7; II Kor. 11:7-12). ${ }^{23}$ Powell menegaskan bahwa disamping Paulus menyebarkan Injil Paulus adalah pembuat tenda, membangunnya dan membongkarnya. ${ }^{24}$ Jadi kebutuhan rasul Paulus bukan hasil dari pemberian orang yang ia layani, tetapi dengan tangannya sendiri dengan profesi sebagai tukang tenda. Bahkan hasil yang ia dapat dalam pembuatan tenda, Paulus juga masih berbagi dengan orang lain. Packer mengatakan bahwa:

Setelah Paulus melayani orang-orang non-Yahudi selama hampir 3 tahun, di Yerusalem, Paulus kembali ke Antiokhia, dari sana ia menuju Galatia, firgia, Derbe, Listra, Ikonium, dan Antiokhia. Setelah itu ia memutuskan untuk menginjili secara intensif di Efesus. Di Efesus inilah Paulus menunjukkan tahun-tahun paling berat baginya, dimana ia harus menghidupi dirinya sendiri dengan membuat dan menjual tenda-tenda. Dimana rasul Paulus pagi-pagi benar dia mulai membuat tenda, siang harinya dia mengajar, dan memberitakan Injil, kemungkinan hingga malam hari. ${ }^{25}$

\footnotetext{
${ }^{22}$ William B. Erdmans, Exegetical Dictionary of the New Tastament Vol 3 (Michingan: Publishing Company Grend Rapids, 1993), 472

${ }^{23}$ Marshall, Kumpulan Komentari Panduan belajar Perjanjian Baru Vol 8(EAST: Texas babtis University 1997),

${ }^{24}$ Paul W. Powell, Tuhan mengapa harus terjadi (Jakarta: Gunung Mulia, 2000), 49

${ }^{25}$ J.I Packer, Merril C, The World of the New Testament (Surabaya: Gandum Mas, 1993), 214
} 
Paulus bekerja dengan tangannya sendiri sehingga dapat menolong kawan-kawan sekerjanya. Hal ini tentu sangat sulit bagi pemberita Injil, akan tetapi ia sungguh-sungguh berusaha agar dapat memenuhi keperluannya sendiri. Basuki mengatakan bahwa "melayani Tuhan harus dengan motifasi yang murni." Paulus menuliskan dalam 2 Tim 1:3, aku mengucap syukur kepada Allah, yang kulayani dengan hati nurani yang murni seperti yang dilakukan nenek moyangku dan selalu aku mengingat engkau dalam permohonanku baik siang maupun malam ${ }^{26}$. Dalam melayani Tuhan harus harus memiliki motifasi yang murni. Artinya pelayanan kita kepada Dia bukan karena pamrih atau pahala, melainkan karena ucapan syukur kepadaNya yang telah memilih, menyelamatkan dan melayakkan kita untuk melayaniNya.Paulus menekankan kepada setiap pelayan Tuhan, supaya memiliki motifasi yang benar dalam melayani Tuhan.

Seperti Wiersbe mengemukakan bahwa: "Niat hati seorang pelayan Tuhan haruslah untuk memuji Tuhan, bukan untuk dipuji, untuk mendapatkan upah kekal disurga, bukan pengakuan sesaat di dunia”. "Engkau tidak akan memperoleh upahmu dua kali” (Mat. 6:118). Pada hari penghakiman, banyak orang yang saat ini menjadi yang terdahulu di mata manusia akan menjadi yang terakhir di mata Allah. sebaliknya banyak yang terakhir di mata manusia akan menjadi yang terdahulu di mata Allah (13:30). Jika niat hati kita benar, Allah pasti akan memberi kita upah yang setimpal meskipun kita tidak berniat mengejar upah. Bila kita melayani orang lain dari hati yang tulus, kita sedang mengumpulkan harta di sorga (Mat. 6:20) dan menjadi "kaya di hadapan Allah" (12:21)". ${ }^{27}$ Artinya bahwa hamba di tuntut untuk memiliki motifasi yang benar dalam pelayanan. Scougal mengatakan:

Jika kamu telah mengalami kasih yang mendalam kepada Kristus dan telah belajar untuk tinggal di dalam Dia, berpeganglah kepadaNya dengan seluruh kekuatanmu.Jangan biarkan dirimu diperdaya untuk mengejar hal-hal yang sia-sia dari dunia ini.Saya tahu bahwa hal-hal itu tampaknya memberikan sukacita, rasa aman, dan kepuasan, namun sesungguhnya semuanya itu hanyalah angan-angan. ${ }^{28}$

Hal ini menjelaskan bahwa seorang hamba Tuhan harus hidup bergantung sepenuhnya kepada Tuhan, sebab upah bagi orang yang menjadi murid sejati ialah ia

\footnotetext{
${ }^{26}$ Yusuf Eko Basuki, Pertumbuhan Iman yang Sempurna(Yogyakarta: Garudhawacara, 2014), 19

${ }^{27}$ Warren W. Wiersbe, Tegu Di Dalam Kristus (Bandung: Kalam Hidup, 2008), 16-17

${ }^{28}$ Henry Scougal, God's Abundant Life (Surabaya: Momentum, 2005), 116
} 
menjadi semakin serupa dengan Yesus Kristus dan kelak akan mendapat bagian dalam kemuliaanNya.

Menurut Calvin, kita seharusnya tidak perlu mengharapkan kekayaan, kehormatan, atau kekuasaan, tetapi kita seharusnya percaya sepenuhnya bahwa segala sesuatu hanya tergantung pada berkat Ilahi". ${ }^{29}$ Maksdunya bahwa kehormatan, kekayaan bukanlah yang utama dalam pelayanan, tetapi bagaimana orang percaya dan hamba Tuhan menyadari bahwa apa yang ada di dunia ini berasal dari Tuhan. Dan sebagai murid memiliki motifasi yang benar di hadapan Allah. Artinya kekayaan dan kehormatan bukanlah yang utama dalam melayani Tuhan, tetapi bagaimana seorang hamba sungguh-sungguh mau melayani Tuhan hanya bergantung kepada Tuhandan murni hanya untuk Tuhan.

\section{Rasul Paulus bertekad "Aku Menyelesaikan Pelayanan"}

Menyelesaikan pelayanan dalam bahasa Yunani memakai kata ' $\tau \varepsilon \lambda \varepsilon \imath \omega ́ \sigma \alpha l$ ' dari kata dasar $\tau \varepsilon \lambda \varepsilon \imath o ́ \omega$ (teleioō)". ${ }^{30}$ dalam bentuk Verb Aorist Active yang artinya kata kerja yang dilakukan secara aktif. Memiliki arti menyelesaikan, habis, terjadi, berhasil memenuhi. Dalam Kamus Besar bahasa Indonesia kata "menyelesaikan" diartikan menyudahkan, menyempurnakan, menjadikan berakhir, menamatkan. ${ }^{31}$ Paulus yang terberkati itu tidak menghiraukan nyawanya sedikitpun demi hal itu bertekad dalam kekuatan Kristus, bahwa dia tidak akan kehilangan tujuan hidup hanya demi mempertahankan nyawanya. Dia rela menjalani hidupnya dengan bekerja keras, mempertaruhkan nyawanya dalam pelayanan yang berbahaya, dan menghabiskan waktunya untuk pelayanan yang melelahkan.Bahkan dia rela menyerahkan nyawanya sebagai martir, sehingga Paulus menggenapi maksud dari kelahirannya, babtisannya, dan panggilannya. ${ }^{32}$ Artinya Rasul Paulus mengambil tekad untuk tetap setia melayani Tuhan, sekalipun banyak pencobaan yang Paulus hadapi, bahkan nyawa sekalipun Paulus pertaruhkan. Park Mengatakan bahwa:

Pencobaan dari pihak orang Yahudi yang mau membunuh aku, diantara pencobaan yang paling menyedihkan yang dialami orang percaya, adalah pencobaan berupa ancaman rencana jahat dari sesama manusia. Orang yang menerima pencobaan itu harus meminum cawan pahit kesendirian,

\footnotetext{
${ }^{29}$ John Calvin, Sebuah Hati Untuk Ketaatan (Surabaya: Momentum, 2014), 244

${ }^{30}$ Hasan susanto, Perjanjian Baru Interlinear Yunani-Indonesia dan Konkordansi Perjanjian Baru (PBIK).., 753,827

${ }^{31}$ Dendy Sugono, Kamus Besar Bahasa Indonesia (Jakarta: Gramedia Pusat Bahasa, 2011),752

${ }^{32}$ Matthew Henry, Kitab Kisah Para rasul (Surabaya: Momentum, 2014), 870
} 
akan tetapi kesendirian adalah obat yang baik untuk memandang dan bersandar hanya kepada Tuhan serta percaya hanya kepadaNya. ${ }^{33}$

Hal-hal tersebut menimpa Paulus dari pihak orang Yahudi yang mau membunuhnya, yang masih berkomplot untuk merancangkan kejahatan melawannya. Perhatikanlah para hamba Tuhan yang setia akan terus melanjutkan pelayanan mereka bagiNya di tengah-tengah aral dan bahaya, tanpa menghiraukan sedikit pun musuh-musuh macam apa yang harus mereka hadapi, supaya mereka dapat membuktikkan diri layak di hadapan Guru mereka dan menjadikan Dia sahabat mereka.

Calvin menuliskan tentang kerendahan hati kita dan kehebatan atau pengagungan Allah: kerendahan hati kita adalah kehebatanNya, sehingga pengakuan dari kerendahan hati kita menyediakan pemulihan dalam belas kasihanNya. ${ }^{34}$ Artinya bahwa pelayanan tidak akan berakhir dengan baik jika seorang pelayan Tuhan tidak memiliki kerendahan hati

Kerendahan hati dalam bahasa Yunani memakai kata $\tau \alpha \pi \varepsilon$ vo (tapeinophrosune) yang artinya "kerendahan hati". Dengan kasus kata benda feminine singular genitive. ${ }^{35}$ Dalam King James Version memakai kata "humility of mind", yang artinya menjaga kerendahan hati dari pikiran, akal, ingatan. ${ }^{36}$ Dalam New American Standard memakai kata "afflict, (menyebabkan hati menderita, menimpa), Oppress (menekan), Humble (sederhana, rendah, merendahkan hati). ${ }^{37}$ Dalam kamus Alkitab kerendahan hati artinya sifat baik, yang dalam Perjanjian Lama ditunjukkan dengan perilaku lahiriah seperti menangis, berpuasa, dan mengoyakkan jubah (1 Raj. 21:29; 2 Raj. 22:11-20). Jadi secara harafiahnya kerendahan hati ialah menjaga hati, pikiran akal, sederhana dan merasa tidak berdaya.

Dalam Perjanjian Baru kerendahan hati adalah merasa tak berdaya seperti anakanak (Matius 18:4), tidak mempertahankan kedudukan (Filipi 2:8-9), atau tidak merendahkan kedudukan. ${ }^{38}$ Rendah hati artinya tidak menganggap diri lebih hebat atau lebih kuat dari pada orang lain. Seperti halnya rasul Paulus mengungkapkan kepada para

\footnotetext{
${ }^{33}$ Yune Sun Park, Tafsiran Kisah Para Rasul (Malang: Departemen Literatur Kristen Indonesia, 2001), 300

${ }^{34}$ John Calvin, Sebuah hati untuk ketaatan (Surabaya: Momentum, 2014),9

${ }^{35}$ Op.cit $752-745$

${ }^{36}$ Spiros Zodhiates, The Hebrew-Greek Key Study Bible "Bible Publishers, 1475.

${ }^{37}$ Harris, et alls, Theological Wordbook Off The ot $(\mathrm{tt})$

${ }^{38}$ W.R.F Browning, Kamus Alkitab (Jakarta: BPK Gunung Mulia 2011), 197
} 
penatua yang ada di Efesus. Rasul Paulus menyatakan bahwa dengan segala rendah hati aku melayani Tuhan.

\section{Rasul Paulus "Memberi Kesaksian"}

Memberi kesaskian dalam bahasa Yunani memakai kata " $\delta l \alpha \mu \alpha \rho \tau \dot{\rho} \rho \alpha \sigma \theta \alpha l$ " dari

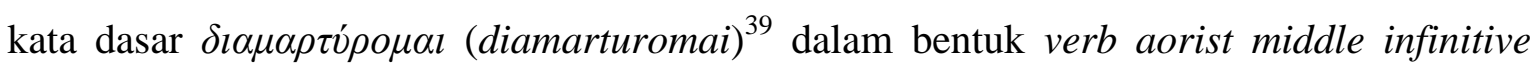
yang artinya kata kerja yang dilakukan terus menerus yang memiliki arti bersaksi, memberi kesaksian, memperingati. Dalam Kamus Besar bahasa Indonesia kata 'kesaksian' memiliki arti menyatakan. ${ }^{40}$ Dalam Firman Allah Yang Hidup mengatakan "tetapi apalah artinya hidup saya ini, jika saya tidak melaksanakan pekerjaan yang ditugaskan kepada saya oleh Tuhan Yesus, yaitu mengabarkan berita kesukaan mengenai kasih dan kebaikan Allah yang Mahabesar." ${ }^{41}$ Secara harafiahnya tugas bagi hamba Tuhan dan bagi orang percaya ialah memberi kesaksian lewat pengajaran dan pemberitaan kabar baik bagi orang percaya maupun bagi mereka yang belum mengenal Injil.

Pekabaran Injil adalah pemberitaan kabar gembira tentang Tuhan dengan maksud supaya orang yang mendengar berita itu mengambil keputusan untuk bertobat kepada Kristus. Pekabaran Injil ditujukan kepada orang-orang yang belum mengenal Injil sama sekali, bahkan tidak tertutup kemungkinan juga bagi orang Kristen yang sudah lama meninggalkan Tuhan, dengan maksud supaya semua orang itu menyerahkan kehidupannya secara penuh kepada Tuhan. ${ }^{42}$ Seperti halnya dikatakan oleh Metzger bahwa:

Apa yang terjadi seandainya seorang dokter ahli bedah yang sedang mengerjakan pembedahan pasien yang gawat, tiba-tiba menyadari bahwa pisau bedahnya tidak ada? Ia akan berseru dengan cemas, "saya tidak mempunyai alat yang tepat untuk membuat irisan ini" kita pun terpanggil untuk menjadi dokter yang mengobati jiwa-jiwa. Kita sudah diberi pisau bedah, namun terkadang kita lupa menggunakannya padahal alat ini mutlak diperlukan untuk membedah hati orang-orang yang belum percaya. $^{43}$

Jadi memberitakan Injil adalah tanggungjawab setiap orang percaya. Allah yang memanggil dan memilih setiap orang percaya untuk menyatakan rahasiaNya kepada umatNya. Sebagai hamba yang setia senantiasa memiliki motifasi yang benar dalam melayani Tuhan, dan hanya fokus kepada kebenaran. Memberitakan Injil buakanlah

\footnotetext{
${ }^{39}$ Ibid.,

${ }^{40}$ Ibid., 732

${ }^{41}$ Oman Y.H Firman Allah Yang Hidup (Bandung: Kalam Hidup, 1975), 201

${ }^{42}$ Malcolm Brownlee, Tugas Manusia Dalam Dunia Milik Tuhan (Jakarta: Gunung Mulia, 2011), 30

${ }^{43}$ Will Metzger, The Truth (Surabaya: Momentum, 2005),55
} 
paksaan, atau tidak dengan rela hati tetapi sebagai orang percaya yang telah diselamatkan dan dibebaskan tugasnya hanyalah menyampaikan dan mengajarkan kabar baik kepada semua orang.

\section{$\underline{\text { Kajian Teologis }}$}

Penulis akan membahas dalam kajian theologis tentang kesetiaan pelayanan dan pengorbanan, mengakhiri dengan baik, dan kesetiaan memberitakan Injil.

\section{Kesetiaan Pelayanan dan Pengorbanan}

Wong mengatakan hidup Paulus tidak berarti baginya, melainkan tidak berarti ketika dibandingkan sesuatu dengan yang lain. sesuatu yang lain itu adalah menyelesaikan tujuan dengan sukacita, menggenapi pelayanan yang ia terima dari Tuhan Yesus.Setiap pelayan memiliki tujuan yang harus dijalani dan diselesaikan, sebuah pelayanan untuk orang percaya jalani dan genapi. ${ }^{44}$ Artinya hidup akan sangat berarti jika seorang pelayan Tuhan, menyelesaikan tugas yang telah Tuhan percayakan kepadanya.

Wong mengatakan bahwa Paulus percaya bahwa hidupnyaadalah milik Allah. Paulus tidak khawatir tentang hidupnya dan masa depannya."Tetapi aku tidak menghiraukan nyawaku sedikit pun asal aku dapat mencapai garis akhir dan menyelesaikan pelayanan yang ditugaskan oleh Tuhan Yesus kepadaku untuk bersaksi tentang Injil anugerah Allah. ${ }^{45}$

Keberadaan hidup Paulus di dunia ini ia sadari hanyalah bagi kemuliaan Kristus. Stephen Tong menjelaskan; Allah sumber kita Ia adalah tujuan kita. Allah itu titik permulaan dan titik akhir kita.Sehingga dari permulaan kita berasal dari Dia dan berlangsung proses hidup untuk menyenangkan hati Tuhan. ${ }^{46}$

Rasul Paulus membuktikkan kesetiaannya dengan perkataan aku tidak lalai memberitakan seluruh maksud Allah kepadamu (ayat 27), artinya Paulus tidak pernah lalai melakukan tugas yang Tuhan perintahkan kepadanya, Rasul Paulus tidak dengan sengaja atau berencana menghindar dari tugasnya memberitakan bagian manapun dari maksud Allah. "Dia tidak pernah menolak memberitakan bagian-bagian paling sulit dari Injil hanya hanya karena tidak mau bersusah payah, juga tidak menampik untuk memberitakan bagian-bagian yang yang paling jelas dan mudah hanya untuk mepertahankan gengsinya.Dia tidak menghindari diri untuk memberitakan ajaran-ajaran yang dia tahu

\footnotetext{
${ }^{44}$ David. W.F Wong, Finishing Well.,158

${ }^{45}$ Ibid., 161

${ }^{46}$ Stephen Tong. Peta dan Teladan Allah (Jakarta: Lembaga Reformed Injili Indonesia 2009), 19
} 
akan membuat murka para musuh besar kekristenan, ataupun ajaran-ajaran yang tidak menyenangkan bagi para pemeluknya yang tidak taat, melainkan meneruskan pekerjaannya dengan setia, tidak peduli apakah mereka bersedia mendengarkannya atau menampiknya." ${ }^{47}$ kesetiaanRasul Paulus, sangat terbukti dimana Paulus tidak pernah menghindar dalam tugasnya, bahkan tidak menghirakan kondisi dan situasi.

Machartur berpendapat bahwa"Sebagai pelayan Tuhan harus bertumpu pada kepercayaan, dan kepercayaan dipupuk melalui kesetiaan. Dimana kepercayaan dilahirkan dan penghormatan dipertahankan, ada harga yang harus dibayar, yaitu pelayanan penuh pengabdian. ${ }^{, 48}$ pelayan Tuhan yang memmiliki iman yang kuat, tidak mudah untuk dalam menghadapi apa pu.

Penulis menyimpulkan bahwa kesetiaan dan pengorbanan Paulus sungguh menjadi teladan bagi setiap pelayan Tuhan.Kesetiaannya dan pengorbanannya dimana rela kehilangan nyawa, rela dianiaya rela kehilangan segala-galanya, ini merupakan ciri dari kehidupan seorang pelayan Tuhan rela berjiwa hamba seperti Yesus Kristus.

\section{Pelayanan Dan Finishing Well}

Penulis mengambil beberapa prinsip bagi pelayan Tuhan bagaimana pelayan Tuhan termasuk pelayan-pelayan yang menyelesaikan dengan baikUntuk menyelesaikan dengan baik, pelayan harus mulai sekarang. Wong mengatakan "waktu terbaik untuk menanam sebua pohon adalah dua puluh tahun yang lalu.Waktu kedua terbaik adalah sekarang” apakah kita sudah melakukan dengan baik dimasa lampau, seorang pelayan selalu memulai sekarang untuk menyelesaikan dengan baik. Marthin Luther mengatakan bahwa hanya ada dua hari yang penting sepanjang masa: hari ini dan hari itu. Begitu seoarng pelayan Tuhan dalam mengambil sebuah keputusan bagaimana ingin tampil dihadapan Allah pada hari itu, pelayan Tuhan juga memutuskan bagaimana hidup hari ini. Menyelesaikan dengan baik bukanlah sebuah pertimbangan di masa depan; ia harus menjadi sebuah obsesi masa kini $^{49}$

Marsal mengatakan bahwa "Perak, Emas, dan Pakaian adalah bagian dari kekayaan. ${ }^{, 50}$ Brink berpendapat kekayaan orang-orang zamannya Paulus (Mat 6:19; Yak

\footnotetext{
${ }^{47}$ Matthew Henry, Kitab Kisah Para Rasul.,884

${ }^{48}$ John Machartur, Kitab Kepemimpinan (Jakarta: Gunung Mulai 2004),88

${ }^{49}$ Ibid., 25

${ }^{50}$ Marshall, Kumpulan Komentari Panduan Belajar Perjanjian Baru Vol.8 (EAST: Texas Babtis University, 1997), 294
} 
5:2). New Internasional Version (NIV) berbunyi: "I have not coveted anyone's silver or gold or clothing". ${ }^{51}$ Artinya ia tidak memiliki sumber kekayaan baik emas pakaian.

Berdasarkan pemahaman diatas penulis menyimpulkan bahwa kesetiaan yang dilakukan oleh Rasul Paulus sanagatlah luar biasa jika dibandingkan dengan hamba Tuhan sekarang ini karena tantangan yang Paulus hadapi dalam pelayanan bukanlah tantangan yang biasa akan tetapi rasul Paulus melakukannya dengan teguh supaya Paulus bisa mencapai tujuannya yaitu memberitakan injil.

\section{Rangkuman}

Pelayan Kristus yang baik ialah pelayan yang setia. Loyalty artinya "patuh dan setia" jadi setia berarti sedia mengerjakan perintah itu dengan sikap hati yang benar dan kualitasterbaik sampai akhirnya.Ada pun hal-hal yang dituntut kepada seorang hamba adalah dimana sebagai pelayan-pelayan Tuhan mereka dapat dipercayai, setia dalam melaksanakan tugas mereka sampai akhir.

Paulus mengacu kepada ajaran Yesus yang mengikutsertakan gambaran tentang seorang penatalayan yang setia (Luk. 14:42 16:1-8), bagi Paulus sebagai seorang rasul dan hamba Tuhan yang utama dalam hidupnya untuk tetap setia kepada Tuhan.Hamba Tuhan yang setia adalah hamba yang mencapai garis akhir dan tentu selama melayani Tuhan sangat dibutuhkan kesetiaan seorang hamba. Kesetiaan hamba Tuhan akan diuji oleh waktu dimana ia akan mengalami berbagai penderitaan, kesengasaraan, pergumulan, dan banyak hal yang akan dialami dalam melayani Tuhan. Disinilah akan teruji seorang hamba Tuhan bagaimana kesetiaannya kepada Tuhan. Di dalam kesetiaan hamba dituntut untuk selalu meneladani karakter Kristus yang setia melayani sampai akhir.

Kesetiaan berbicara tentang ketahanan, keteguhan untuk mencapai tujuan khususnya ketika berada dalam bahaya dan bencana.Hal ini menjelaskan kesetiaan dalam melaksanakan tugas dan pengabdian tanpa pamrih pada orang tertentu dan prinsip-prinsip dipegang.kesetiaan - kesulitan, bahaya dan perbedaan-perbedaan. Kesetiaan tidak berarti acuh tak acuh atau bersikap pasif.Tidak juga berarti menahan rasa sakit tanpa mengeluh.Kesetiaan adalah sifat yang positif dan aktif.Kesetiaan berasal dari kasih yang terus mengalir dan keluar sebagai pemenang.Bersikap setia berarti tabah dan mempertahankan kebenaran ketika menghadapi kejahatan.Orang yang setia tidak

\footnotetext{
${ }^{51}$ Ibid
} 
mengesampingkan masalah, atau berusaha untuk melepaskan diri lewat jalan yang mudah, atau menghindar ketika ancaman datang, orang yang setia tetap mengahadapi masalah mereka.

Kesetiaan juga diartikan "ketaatan", ini menggambarkan sebagai sebutan untuk pelaksanaan kewajiban, ketaatan yang teguh pada kebenaran dan kejujuran.Kesetiaan berarti tetap kuat walaupun semua perasaan dan kesulitan, bahkan sukacita yang pernah dialami sekalipun telah sirna. 


\section{DAFTAR PUSTAKA}

Ali, Lukman. (1990). Kamus besar, Jakarta: Balai Pustaka.

Andini T, Nirmala (....). Kamus Lengkap Bahasa Indonesia, Surabaya: Prima Media

Andrew, Murray. (1980). Membina Iman, Bandung:Kalam Hidup.

Barclay, William. (2008). Pemahaman Alkitab Setiap Hari, Jakarta: BPK Gunung Mulia

Bartlett, David L. (2011). Pelayanan Dalam Perjanjian Baru Jakarta: BPK Gunung Mulia.

Benyamin, Sameul. (2010). Perjanjian Baru, Bandung: Bina Media Informasi.

Borrong, Robert P. (2002). Berakar Didalam Dia Dan Dibangun Di Atas Dia, Jakarta: BPK Gunung Mulia.

Brink, H.V.D. (2003). Tafsiran Kisah Para Rasul, Jakarta: BPK Gunung Mulia.

Browning, W.R.F. (2011). Kamus Alkitab. Jakarta: BPK Gunung Mulia.

Brownlee, Malcolm, (...). Tugas Manusia Dalam Dunia Milik Tuhan, Jakarta: BPK Gunung Mulia.

Calvin, John. (2014). Sebuah Hati Untuk Ketaatan, Surabaya: Momentum.

Calvin, John. (2014). Sebuah Hati Untuk Ketaatan, Surabaya: Momentum.

Chamblin, J. Knox. (2009). Paulus dan Diri Surabaya: Momentum.

Drescher, Jhon M. (2008). Melakukan Buah Roh, Jakarta: Gunung Mulia.

Ellis, DW. (2010). Metode Penginjilan Jakarta: Gunung Mulia.

Erdmans, William B. (1993). Exegetical Dictionary of the New Tastament Vol 3, ichingan: Publishing Company Grend Rapids.

Estabrooks, Paul. (2001). Berdiri teguh ditengah badai, Jakarta: Open Doors Internasional.

Green, Jay P. (1976). The Interlinear Greek-English New Testament, Indiana: Associated Publishers \& Authors.

Guthrie, Donald. (2008). Pengantar Perjanjian Baru Volume 1, Surabaya: Momentum.

Henry Scougal. (2005). God's Abundant Life, Surabaya: Momentum.

Henry, Matthew. (2014). Kitab Kisah Para Rasul Surabaya: Momentum.

Kahelai, Willeiem. (2008). Kamus Lengkap, Surabaya: Sulita Jaya. 
Kim, Barnabas. (1998). Khotbah Ekspositori Kisah Para Rasul, Malang: YPPPI.

Marchrtur, John. (2004). Kitab Kepemimpinan, Jakarta: BPK Gunung Mulia.

Marshal, Howard. (1980). Tyndlae New Tastement Comentaries, England: Act. England. Intervasity Press.

Marshall. (1997). Kumpulan Komentari Panduan belajar Perjanjian Baru Vol 8, EAST: Texas babtis University

Merril, J.I Packer. (1993). The World of the New Testament, Surabaya: Gandum Mas.

Metzger, Will Metzger. (2005). The Truth, Surabaya: Momentum.

Newman, Barclay M. (2008). Kisah Para Rasul, Jakarta: Yayasan Karunia Bakti Budaya.

Park, Yune Sun. (2001). Kisah Para Rasul, Malang: Departemen Literatur.

Pfeiffer, Charels. (2001). The Wycliffe Bible Comentary, Malang: Gandum Mas.

Pfeiffer, Charles F. (2001). Tafsiran Alkitab Wycliffe, Malang: Yayasan penerbit Gandum Mas.

Simanjuntak, A. (1980). Tafsiran Alkitab Masa Kini, Jakarta: BPK. Gunung Mulia

Stamps, Donald C. (2006). Alkitab Penuntun Hidup Berkelimpahan, Malang: Gandum Mas.

Subandrijo, Bambang. (2010). Menyingkap Pesan-pesan Perjanjian Baru, Bandung: Bina Media Informasi.

Sugono, Dendi. (2011). Kamus Besar Bahasa Indonesia.

Susanto, Hasan. (2010) Perjanjian Baru Interlinear Yunani Indonesia jilid II, Jakarta: LAI.

Susanto, Hasan. (2010). Perjanjian Baru Interlinear Yunani Indonesia jilid II, Jakarta: LAI.

Tenney, Merrill C. (1997). Survei Perjanjian Baru, Malang: Gandum Mas.

Wesley, Brill. (2008). Tafsiran Surat Tesalonika, Bandung: Kalam Hidup.

Wiersbe, Warren W. (2012). Bertekun di dalam Kristus, Bandung: Kalam Hidup.

Wong, David. W.F. (2011). Finishing Well, Yayasan Haggai Indonesia.

Zodhiates, Spiros. (1475). The Hebrew-Greek Key Study Bible, Bible Publisherss 